\title{
Review of the Stability Analysis for the LANL BSL-3 Building Foundation
}

\author{
F. E. Heuze and J. L. Wagoner \\ Lawrence Livermore National Laboratory \\ Livermore, CA
}

U.S. Department of Energy

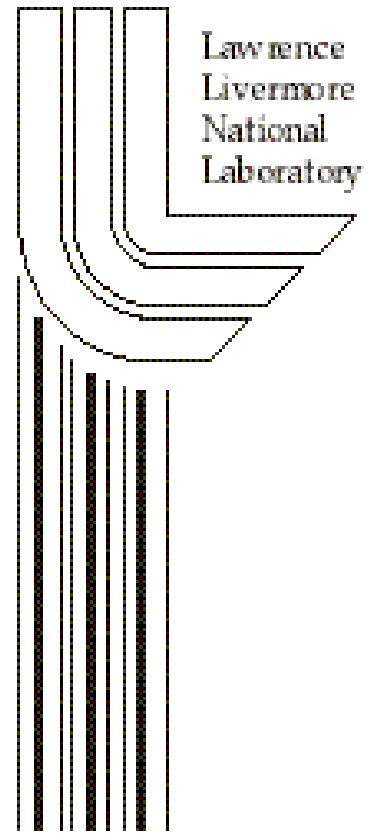

November 2, 2006 


\section{DISCLAIMER}

This document was prepared as an account of work sponsored by an agency of the United States Government. Neither the United States Government nor the University of California nor any of their employees, makes any warranty, express or implied, or assumes any legal liability or responsibility for the accuracy, completeness, or usefulness of any information, apparatus, product, or process disclosed, or represents that its use would not infringe privately owned rights. Reference herein to any specific commercial product, process, or service by trade name, trademark, manufacturer, or otherwise, does not necessarily constitute or imply its endorsement, recommendation, or favoring by the United States Government or the University of California. The views and opinions of authors expressed herein do not necessarily state or reflect those of the United States Government or the University of California, and shall not be used for advertising or product endorsement purposes.

This is a preprint of a paper intended for publication in a journal or proceedings. Since changes may be made before publication, this preprint is made available with the understanding that it will not be cited or reproduced without the permission of the author. 


\title{
Review of the Stability Analysis for the LANL BSL-3 Building Foundation
}

\section{by}

\author{
Francois E. Heuze, and Jeffrey L. Wagoner
}

November 2, 2006

\section{INTRODUCTION}

This work was performed upon request from Dr. Richard Thorpe from NNSA after his review of the LANL report on BSL-3 seismic stability [1].

The authors also reviewed report [1] and concluded, as did Dr. Thorpe, that the stability analysis was inappropriate. There are several reasons for that conclusion:

- the assumption of a circular failure surface through the combined fill-and-rock foundation does not recognize the geologic structure involved.

- the assumption of an equivalent static force to an earthquake loading does not represent the multiple cycles of shear loads created by a seismic event that can engender a substantial degradation of shear modulus and shear strength of the soil under the building [2].

- there was no credible in-situ strength of the foundation materials (fill and rock mass) available for input into the stability analysis.

Following that review, on September 26 the authors made a site visit and held discussions with LANL personnel connected to the BSL-3 building project. No information or evidence was presented to the authors indicating that the static stability of BSL-3 could be an issue. Accordingly, this report focuses on the topic of the BSL-3 site stability under seismic loading.

\section{THE BSL-3 SITE}

The BSL-3 building is within LANL Technical Area 3 (TA-3). An important source of information relevant to seismic hazards for BSL-3 is the final report resulting from a study commissioned several years ago by LANL [3]. Figure 1, shows TA-3 in relation to major faults in the vicinity [3].

Figures 2 to 4, reproduced from [1], give the reader an understanding of the local morphology of the BSL-3 site. Three volcanic tuff layers underlie the fill. They are from the Tshirege member of the Bandelier Formation, and are referred to as Qbt4, Qbt3U, and Qbt3L from youngest to oldest [4]. Figure 5 shows the BSL-3 building and the slope between sections A and C. A visual tour of the site confirmed the static stability of the slopes.

At this time, the thickness of the layers under BSL-3 is not established. However some geotechnical data obtained in area TA-3 are available for these volcanic layers from references [3] and [5], and are summarized in Table 1. 


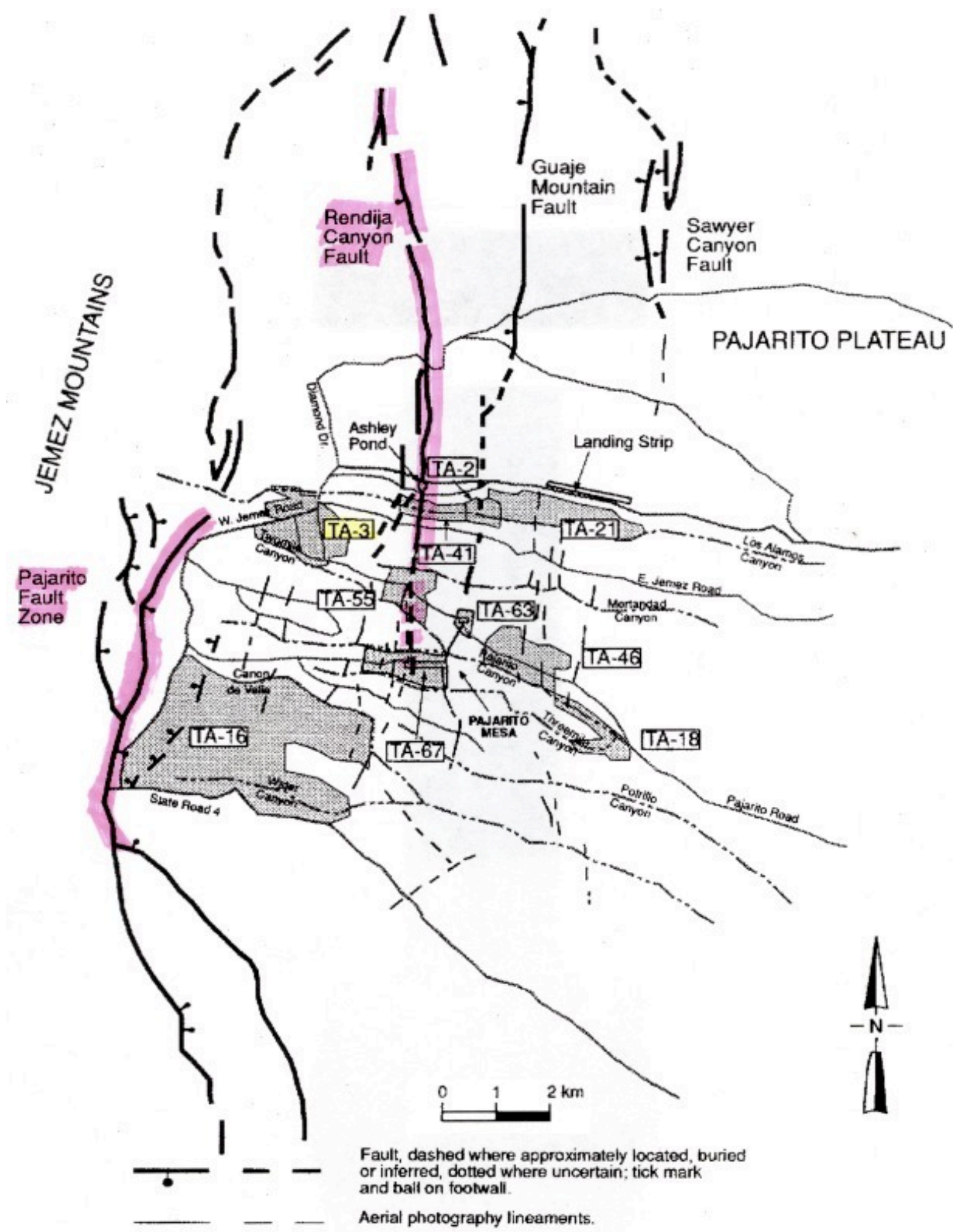

Figure 1. Map of the LANL region showing the Technical Areas and Major Faults (adapted from Fig. 1-1 of [3] vol. 1) 


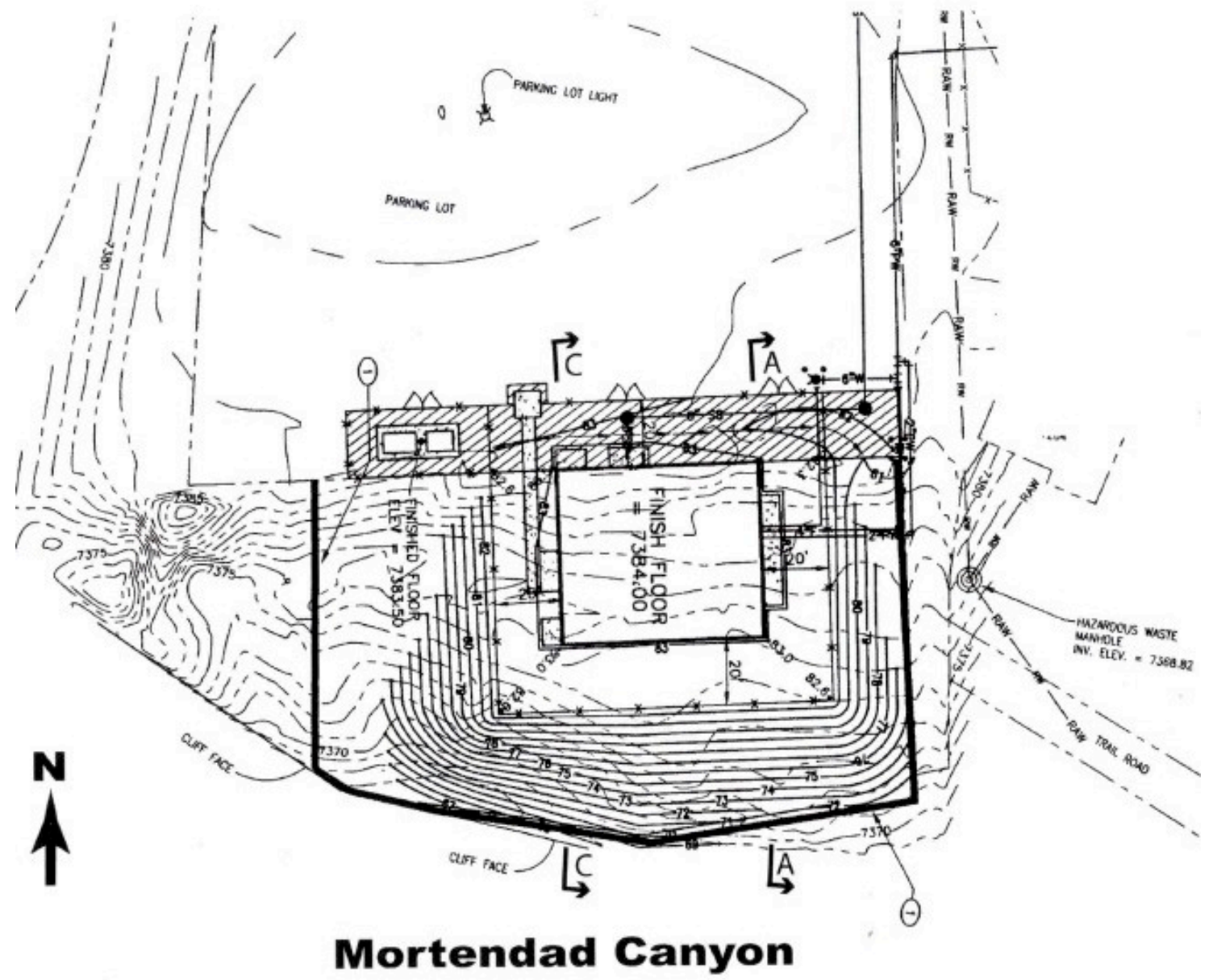

Figure 2. Layout of the building BSL-3 site, showing cross-sections A and C (after [1])

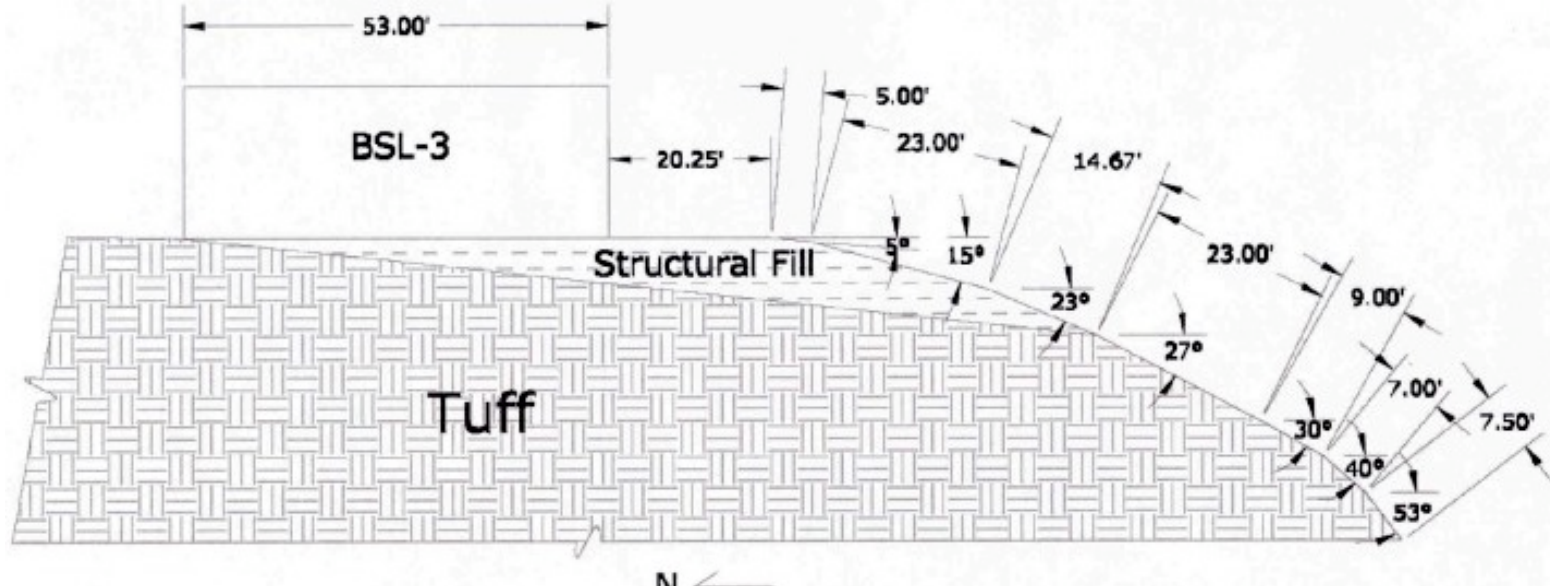

N

Figure 3. Profile geometry of slope A (after [1]) 


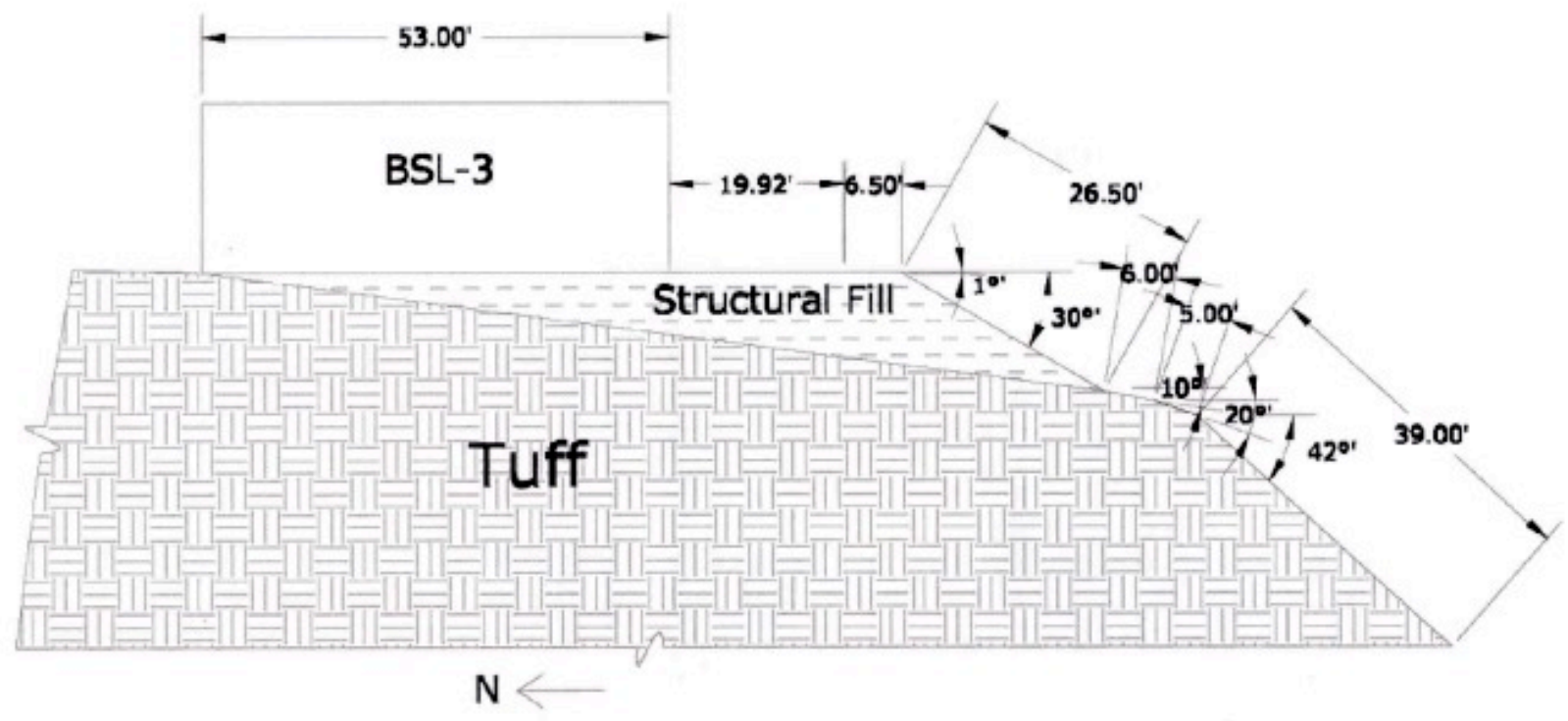

Figure 4. Profile geometry of slope C (after [1])

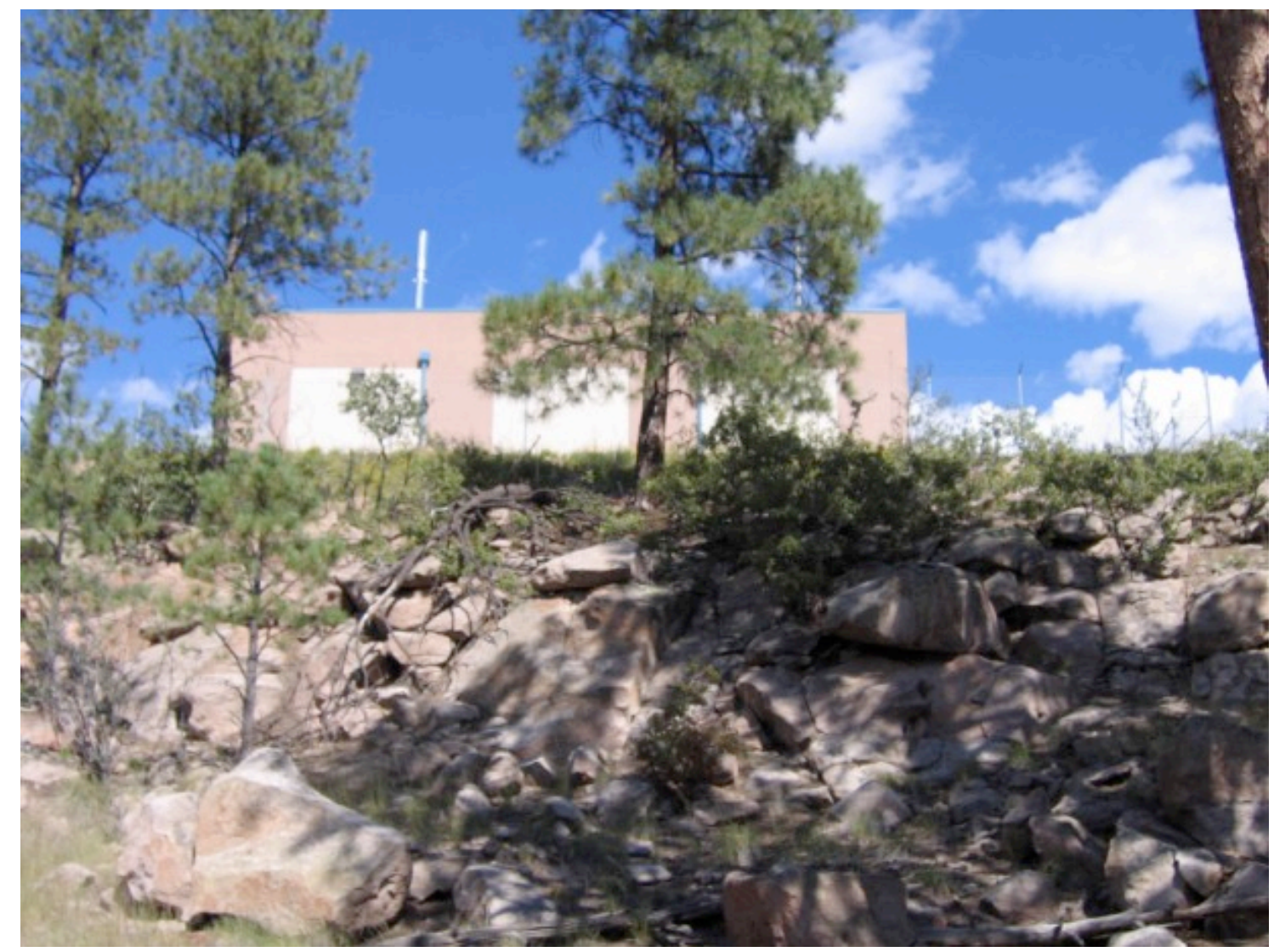

Figure 5. Building BSL-3 and south slope (photo by F. Heuze, Sept 26, 2006) 
Table 1. Geotechnical data for TA-3 tuff layers, after [3] and [5].

\begin{tabular}{|c|c|c|c|}
\hline $\begin{array}{c}\text { Tuff } \\
\text { layer }\end{array}$ & $\begin{array}{c}\text { Rock Mass } \\
\text { Rating } \\
\text { (RMR) }\end{array}$ & $\begin{array}{c}\text { Geologic } \\
\text { Strength Index } \\
\text { (GSI) }\end{array}$ & $\begin{array}{c}\text { Shear Wave } \\
\text { Speed* }^{*} \\
(\mathrm{~m} / \mathrm{s})\end{array}$ \\
\hline Qbt4 & 61 & 56 & 354 \\
\hline Qbt3U & 67 & 62 & 479 \\
\hline Qbt3L & 66 & 61 & 358 \\
\hline
\end{tabular}

${ }^{*}$ Down-hole velocity measurements

\section{SEISMIC ASSUMPTIONS}

The Department of Energy seismic criterion required for BSL-3 is NPH PC-2. Instead, report [1] indicates that the more restrictive PC-3 criterion was used. These criteria are plotted below. PC-3 translated into a $0.306 \mathrm{~g}$ peak horizontal acceleration used in the static slope stability analysis.

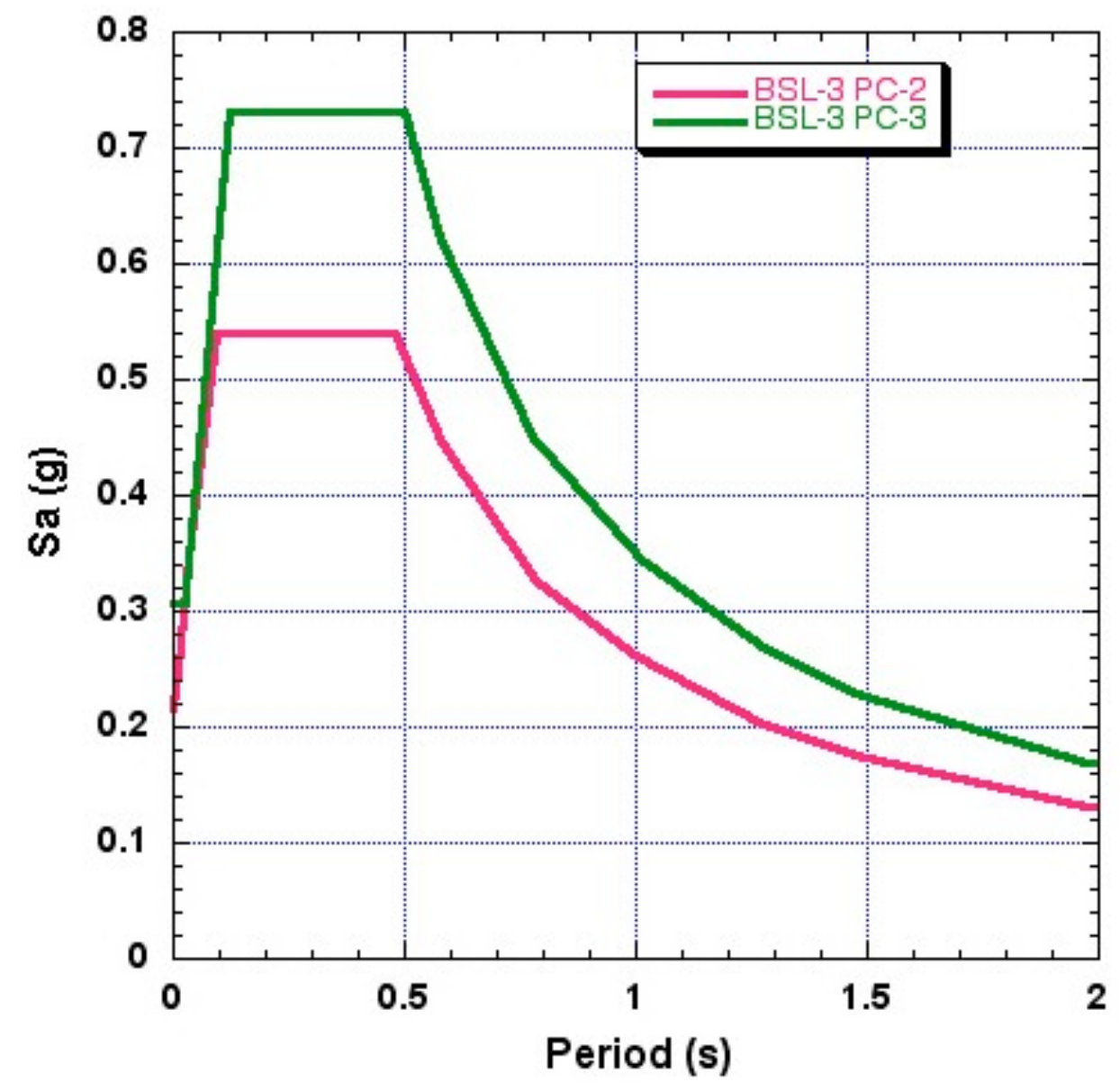

Figure 6. PC-2 and PC-3 criteria specific to LANL BSL-3 building site (plots adapted from [6]) 
Notwithstanding that recent analysis, it is useful and relevant to BSL-3, located in TA-3, to revisit the results of the previous comprehensive seismic study [3] that focuses on the effects of events on fault systems near Los Alamos. Figures 7 to 10 show key figures relevant to LANL's TA-3 seismic exposure.

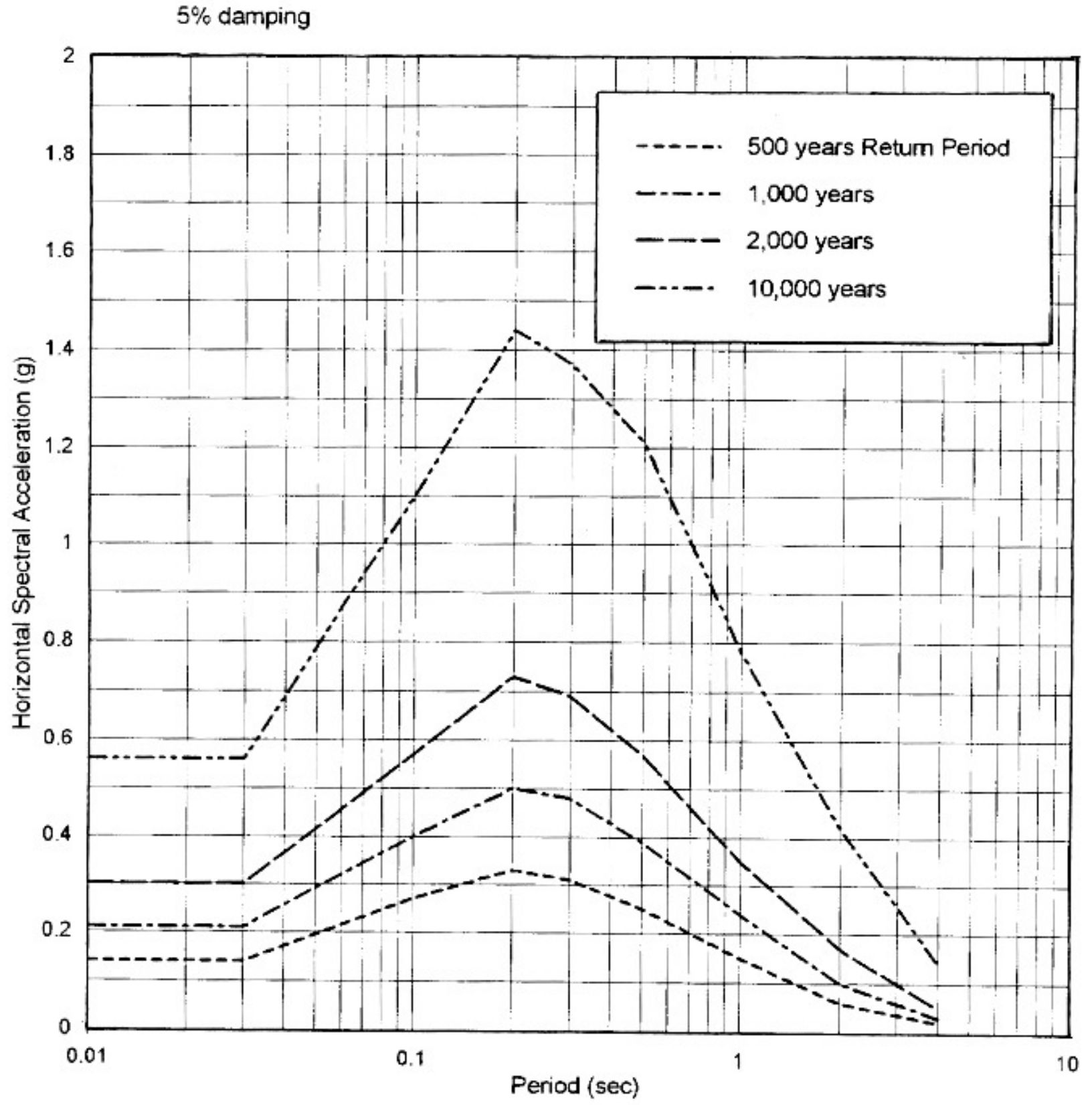

Figure 7. Mean hazard spectra at TA-3 (figure 9-92 of [3]) 


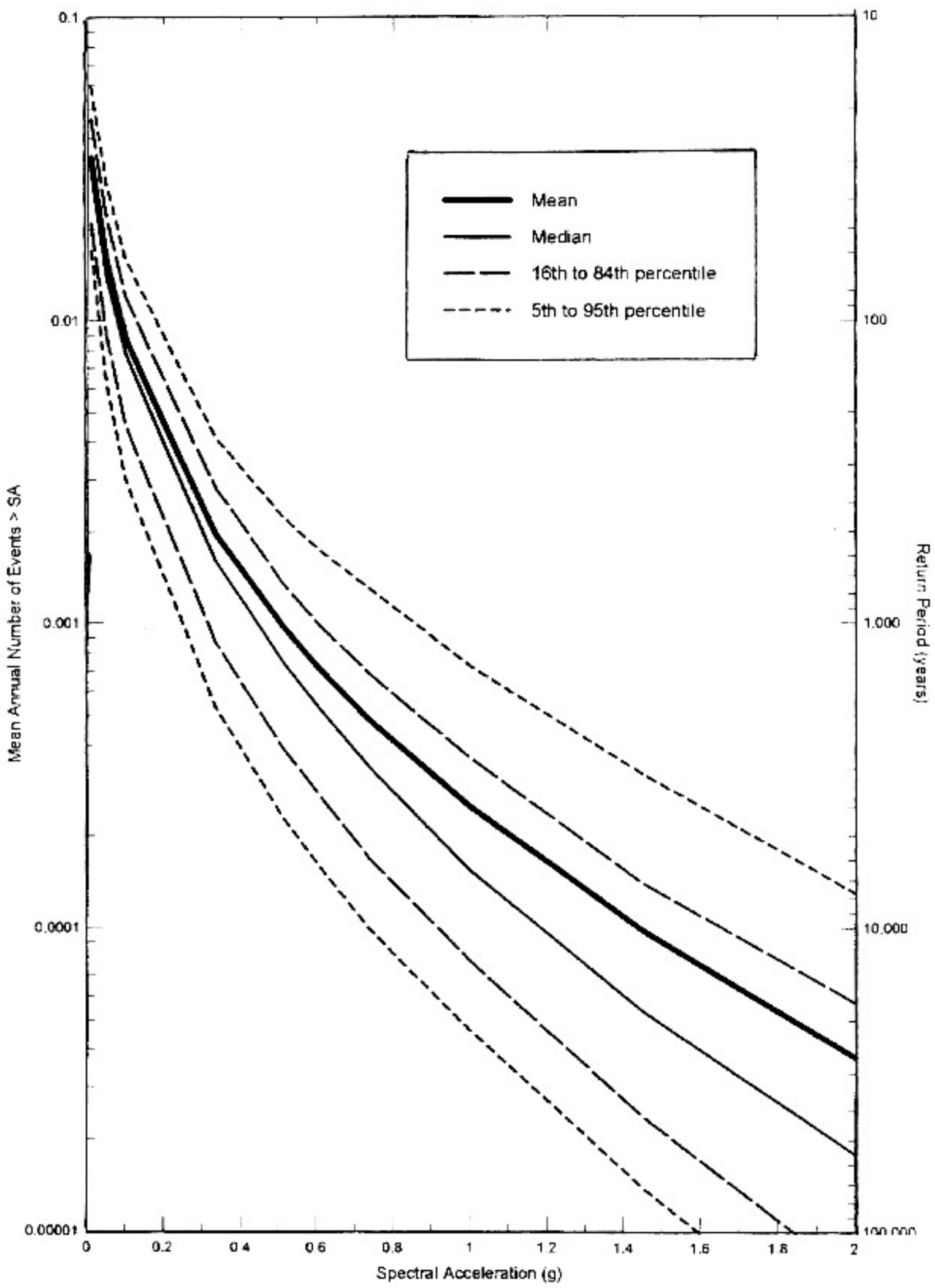

Figure 8. Mean and $5^{\text {th }}$ to $95^{\text {th }}$ percentile curves for $0.2 \mathrm{~s}$ horizontal spectral acceleration at TA-3 (Figure 9-20 of [3]) 


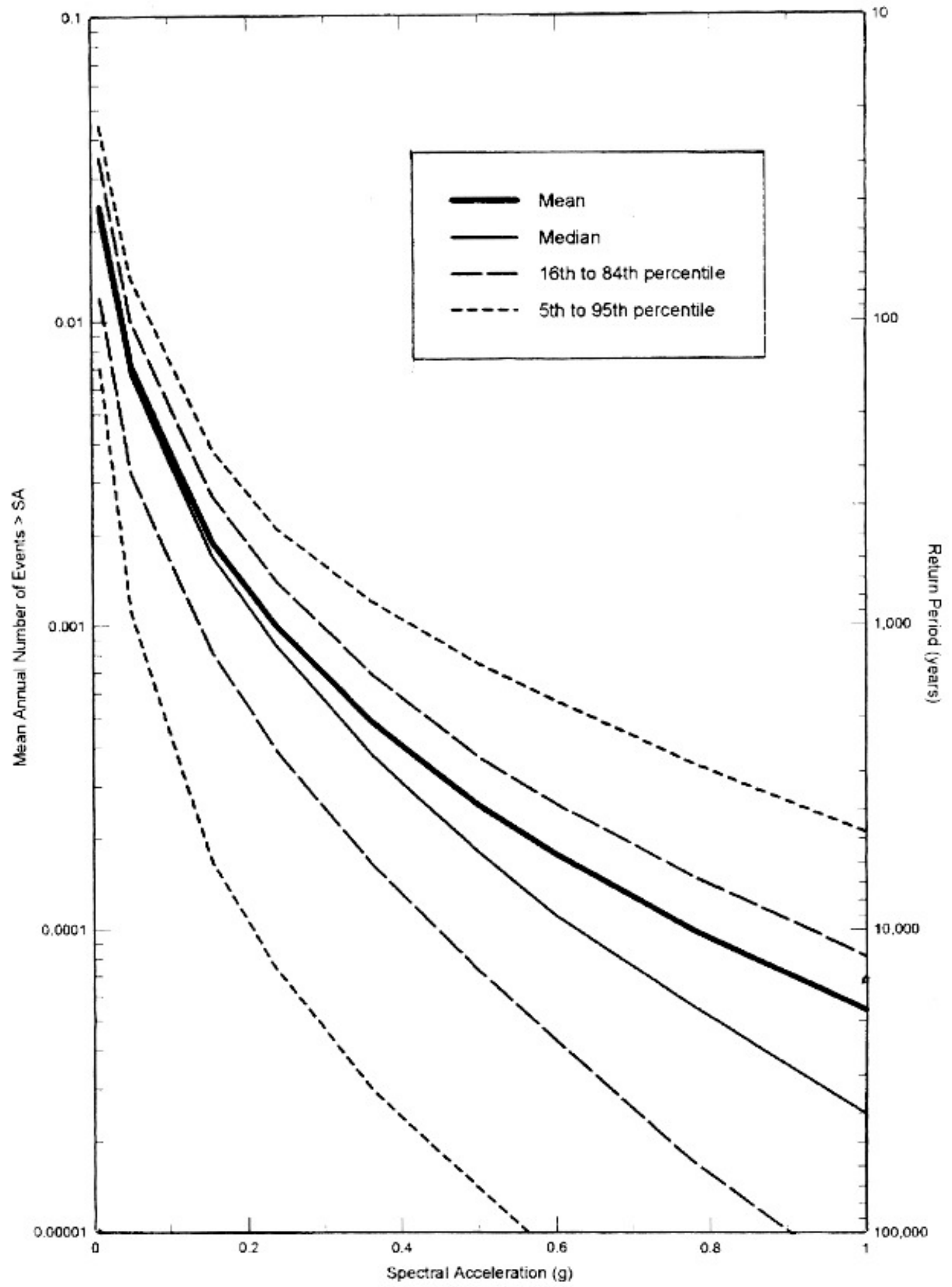

Figure 9. Mean and $5^{\text {th }}$ to $95^{\text {th }}$ percentile curves for 1.0 horizontal spectral acceleration at TA-3 (Figure 9-28 of [3]) 


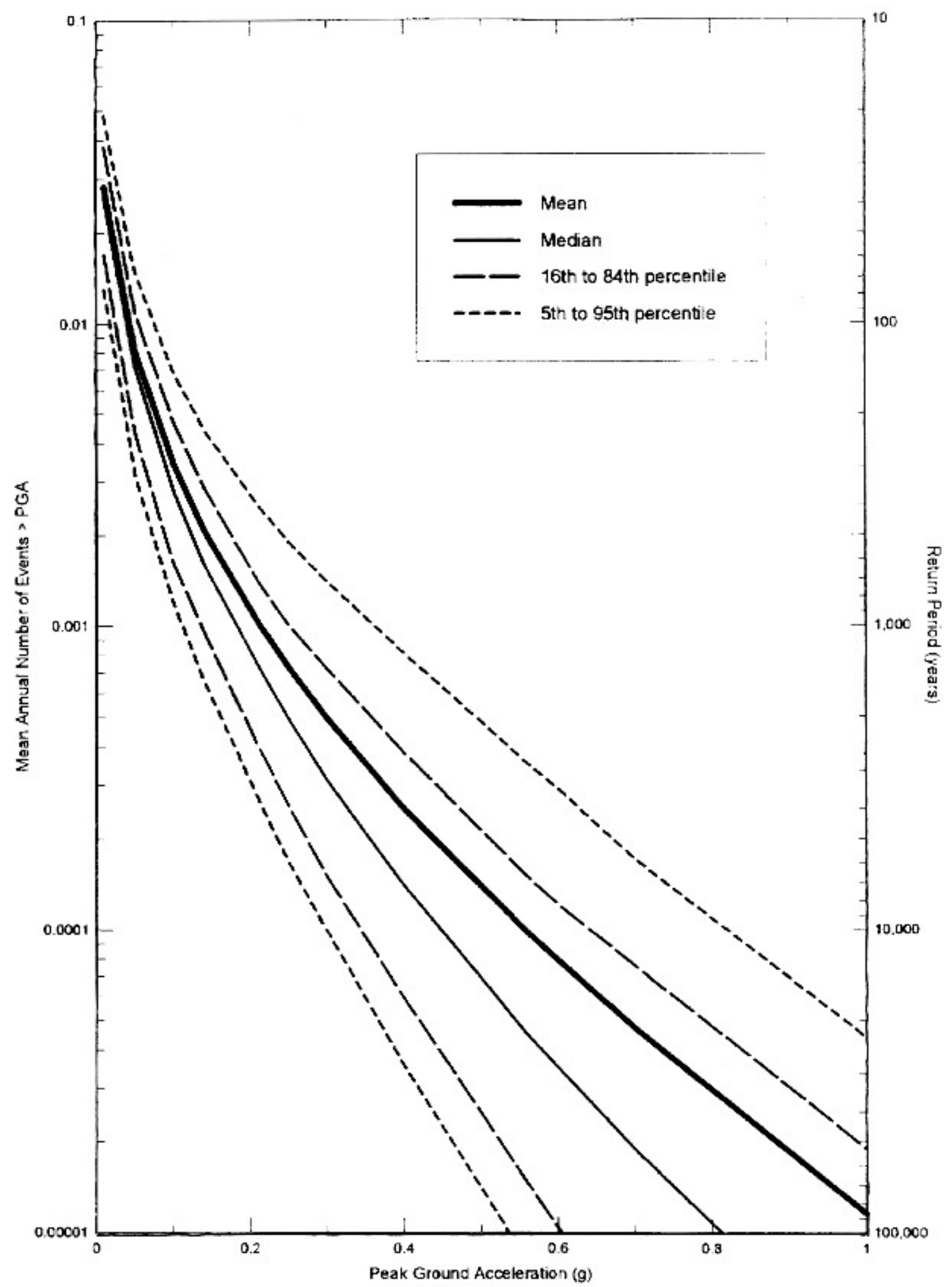

Figure 10. Mean and $5^{\text {th }}$ to $95^{\text {th }}$ percentile curves for peak horizontal acceleration at TA-3 (Figure $9-12$ of [3]) 
The information from Figure 7 was reworked (Figure 11) to plot the mean of TA-3 hazards in a format consistent with the arithmetic axes of Figure 6.

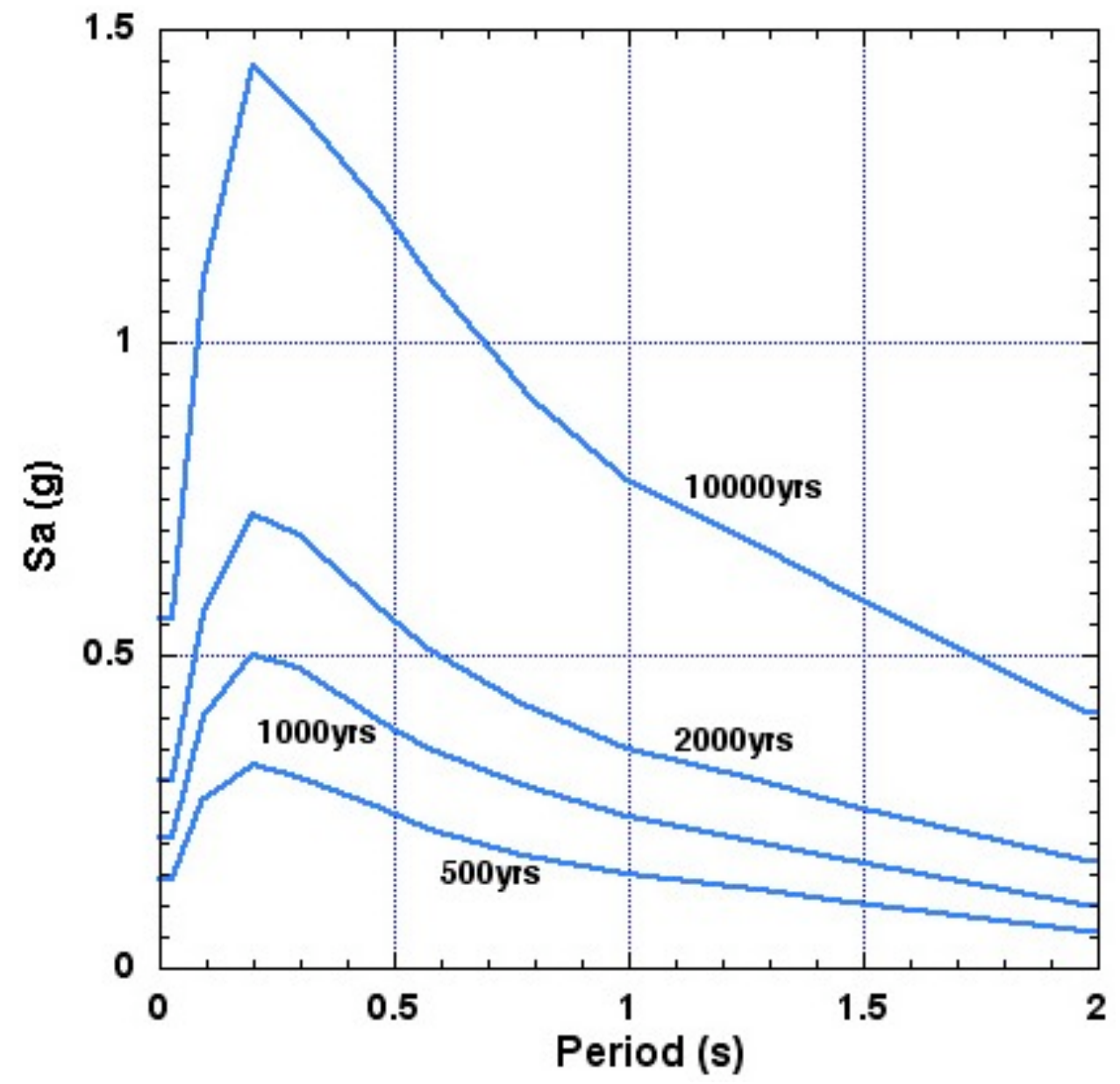

Figure 11. Mean hazard spectra at LANL TA-3 area (adapted from [3])

Figures 8 and 9 enable comparisons of spectral values at mean and $84 \%$ percentile, for periods of $0.2 \mathrm{~s}$ and 1.0s. It can be noted that the amplification factor between the $50^{\text {th }}$ and $84^{\text {th }}$ percentiles varies with the return interval and with the period. However, the differences in those factors for various return intervals change only by plus or minus $2 \%$ between $0.2 \mathrm{~s}$ and $1.0 \mathrm{~s}$. So, the $84^{\text {th }}$ percentile spectra were calculated from the $50^{\text {th }}$ percentile spectra by scaling by the $0.2 \mathrm{~s}$ amplification factor. The results are plotted in Figure 12.

Since the BSL-3 building is in TA-3 one can show the PC-2 and PC-3 criteria specific to its site as compared to the TA-3 hazards. (Figure 13), using the same scales of axes. The comparison indicates that PC-2 is about equivalent to the $50^{\text {th }}$ percentile of the 1000 -year return event and to the $84^{\text {th }}$ percentile of an event with return period between 500 and 1000 years. PC-3 is about equivalent to the $50^{\text {th }}$ percentile of the 2000-year return event and to the $84^{\text {th }}$ percentile of an event with return period between 1000 and 2000 years.

Other metrics of comparison could be used. One is based on the fact that the fundamental period of BSL-3 is between $0.1 \mathrm{~s}$ and $0.15 \mathrm{~s}$ (personal communication from 
T. Houston, LANL). The other is peak acceleration (Figures 6 and10). The $0.15 \mathrm{~s}$ and peak values are compared in Table 2 .

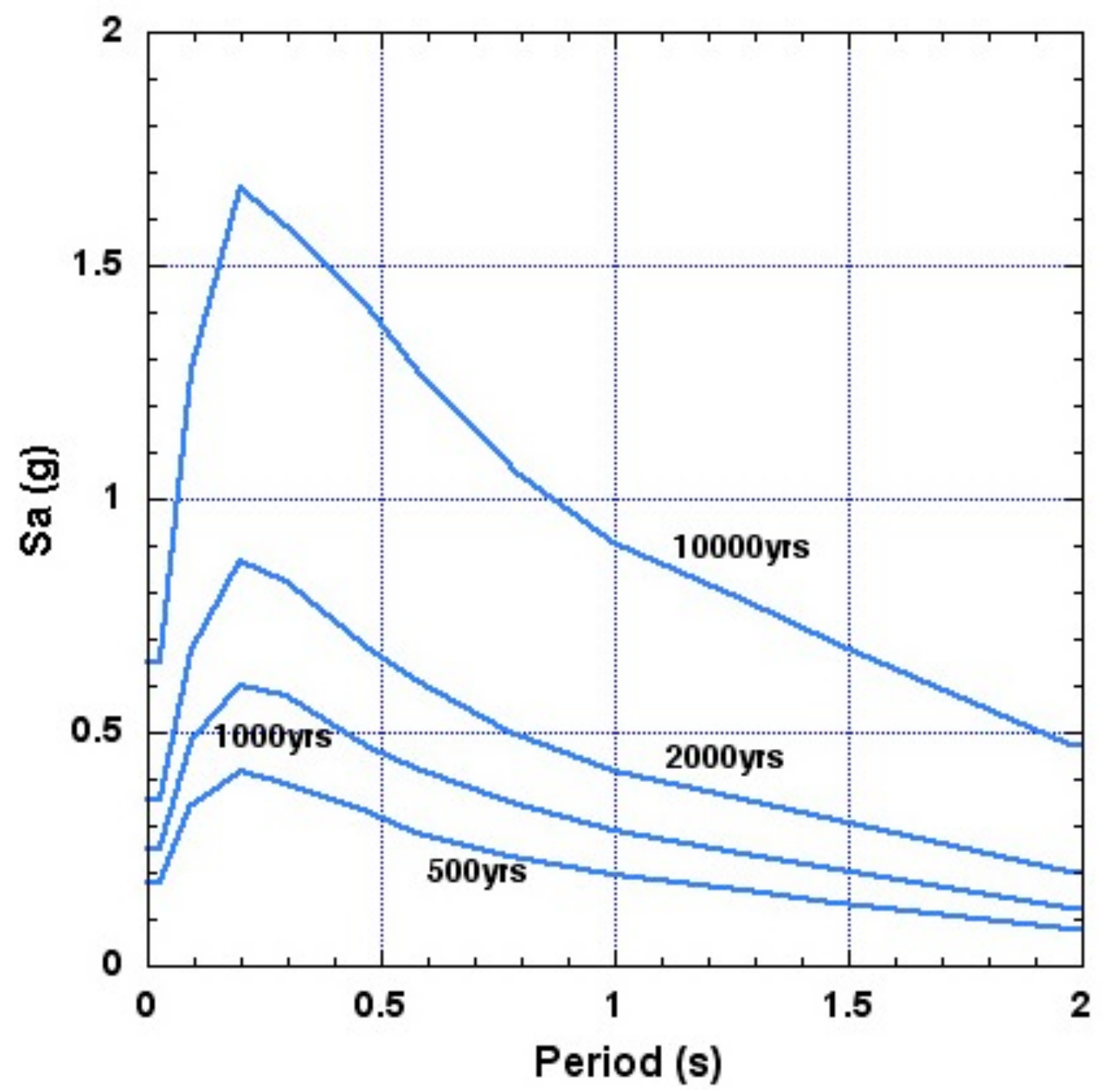

Figure $12.84^{\text {th }}$ percentile hazard spectra at LANL TA-3 area (adapted from [3])

Table 2. Some metrics for comparing LANL BSL-3 PC-2 and PC-3, to LANL TA-3 hazards

\begin{tabular}{|c|c|c|c|c|c|c|c|c|c|c|}
\hline & $\begin{array}{c}50 \% \\
500 \mathrm{y}\end{array}$ & $\begin{array}{c}50 \% \\
1000 \mathrm{y}\end{array}$ & $\begin{array}{c}50 \% \\
2000 \mathrm{y}\end{array}$ & $\begin{array}{c}50 \% \\
10000 \mathrm{y}\end{array}$ & $\begin{array}{c}84 \% \\
500 \mathrm{y}\end{array}$ & $\begin{array}{c}84 \% \\
1000 \mathrm{y}\end{array}$ & $\begin{array}{c}84 \% \\
2000 \mathrm{y}\end{array}$ & $\begin{array}{c}84 \% \\
10000 \mathrm{y}\end{array}$ & PC2 & PC3 \\
\hline $\begin{array}{l}0.15 \mathrm{~s} \\
\text { Sa(g) }\end{array}$ & 0.30 & 0.46 & 0.66 & 1.32 & 0.38 & 0.55 & 0.78 & 1.50 & 0.54 & 0.731 \\
\hline $\begin{array}{r}\text { Peak } \\
\text { ac. (g) }\end{array}$ & 0.16 & 0.215 & 0.30 & 0.55 & 0.195 & 0.24 & 0.36 & 0.65 & 0.22 & 0.306 \\
\hline
\end{tabular}




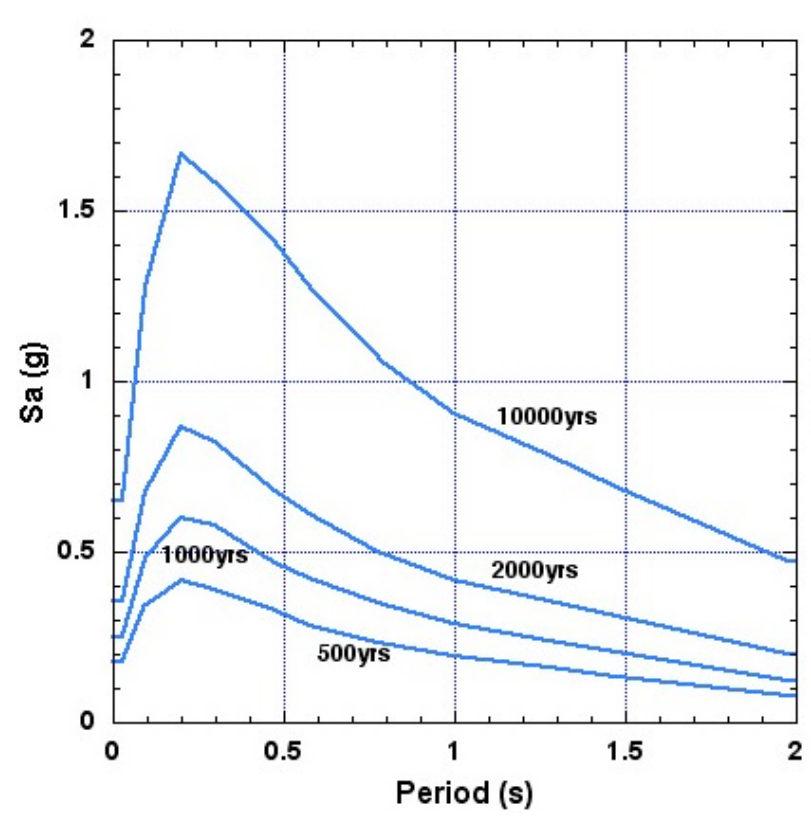

a) TA-3, $84^{\text {th }}$ percentile hazard

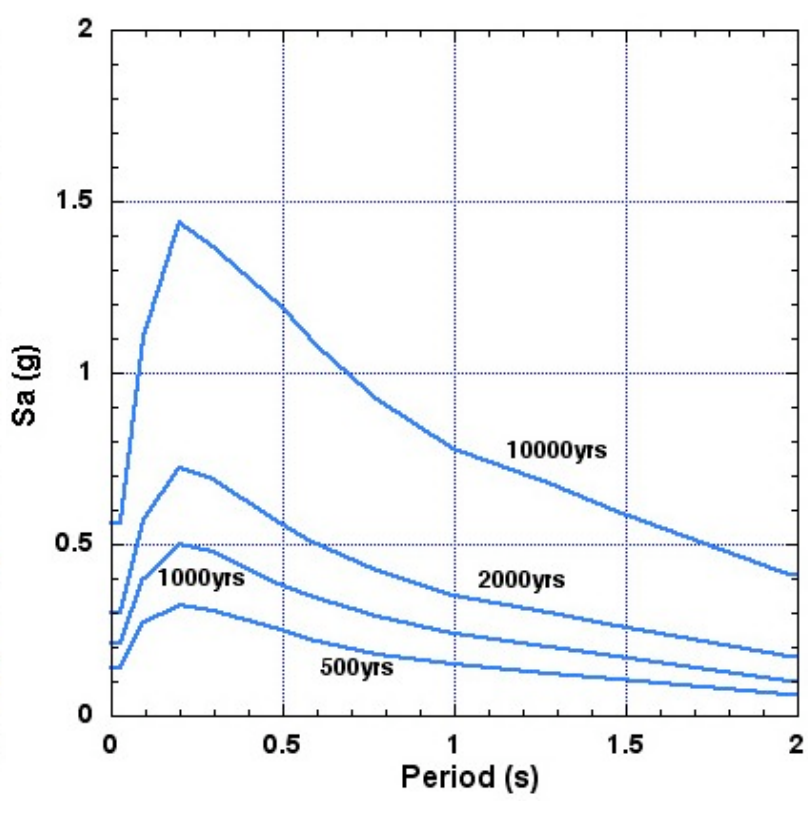

b) TA-3, $50^{\text {th }}$ percentile hazard

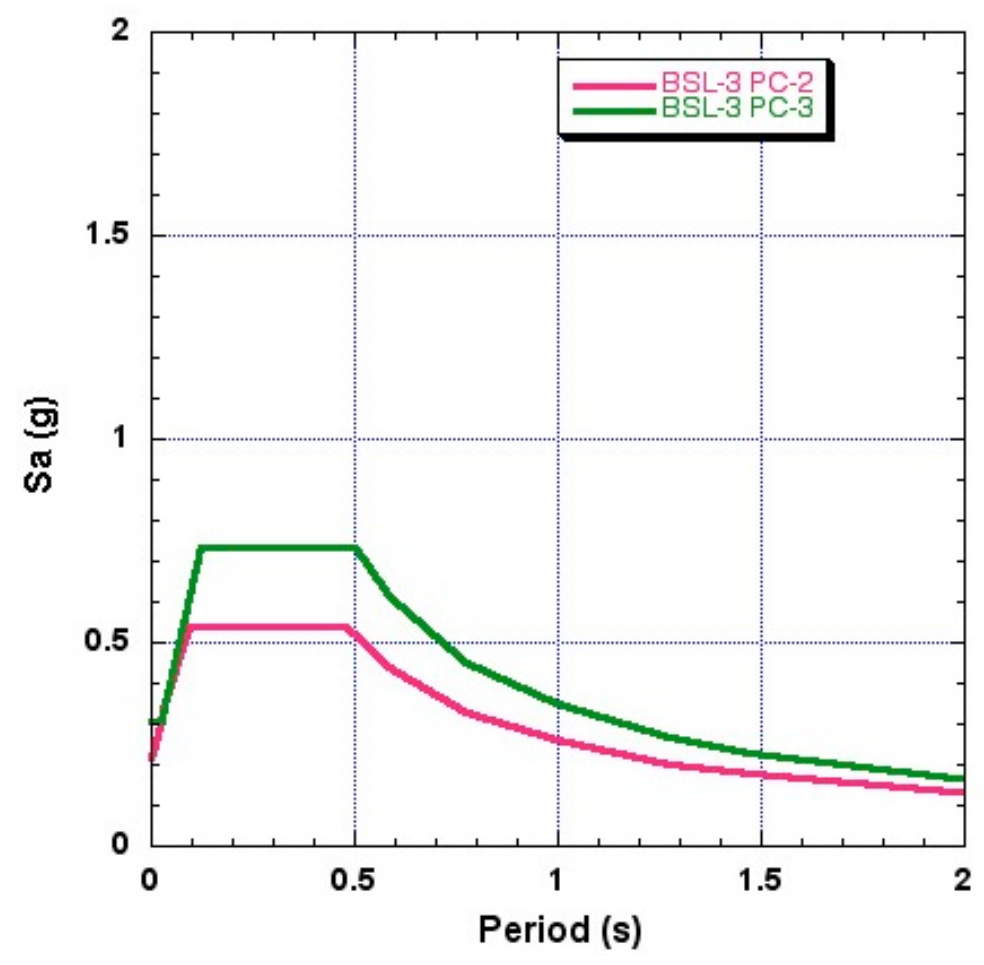

c) BSL-3 PC-2 and PC-3 criteria

Figure 13. Comparison of the PC-2 and PC-3 criteria specific to LANL BSL-3, with the $50^{\text {th }}$ percentile and $84^{\text {th }}$ percentile hazards at LANL TA-3 that contains the BSL-3 site. 


\section{DISCUSSION}

It follows from the above that conclusions regarding the stability of BSL-3 site in [1] result from a very simplified analysis that does not reflect the seismic solicitations that may be put on the site by an earthquake originating on the Pajarito fault zone, or the Rendija Canyon fault [7].

If NNSA considers requesting that new analyses be performed, we suggest the following:

- construct a 3-D computational model of the site showing the fill layer and the three tuff layers. The sloping contact between fill and rock should be modeled as a possible slide surface. The vertical boundaries of the 3-D mesh should be non-reflecting ("silent").

- establish the relevant properties of the fill and rock layers: thickness, mass density, shear wave speed, and initial shear modulus. The model should be able to represent the changes in shear modulus and in damping ratio with shear strain for the fill. An example of such behavior for a SW-SM soil is given in Figure 14.

- drive the base of the 3-D model with horizontal velocity time-histories compatible with the spectrum or spectra of interest. These time-histories should be applied separately both in the N-S and E-W directions. Note that, because the spectral plots do not explicitly account for nonlinear soil response, surface-compatible time-histories should be de-convolved linearly to the base of the model and then propagated upward in nonlinear fashion.

- determine the shear stresses and displacements under the BSL-3 building.

- establish whether shear failure occurs at the site. A particular zone of interest is the contact surface between the fill and the Qbt4 tuff layer.

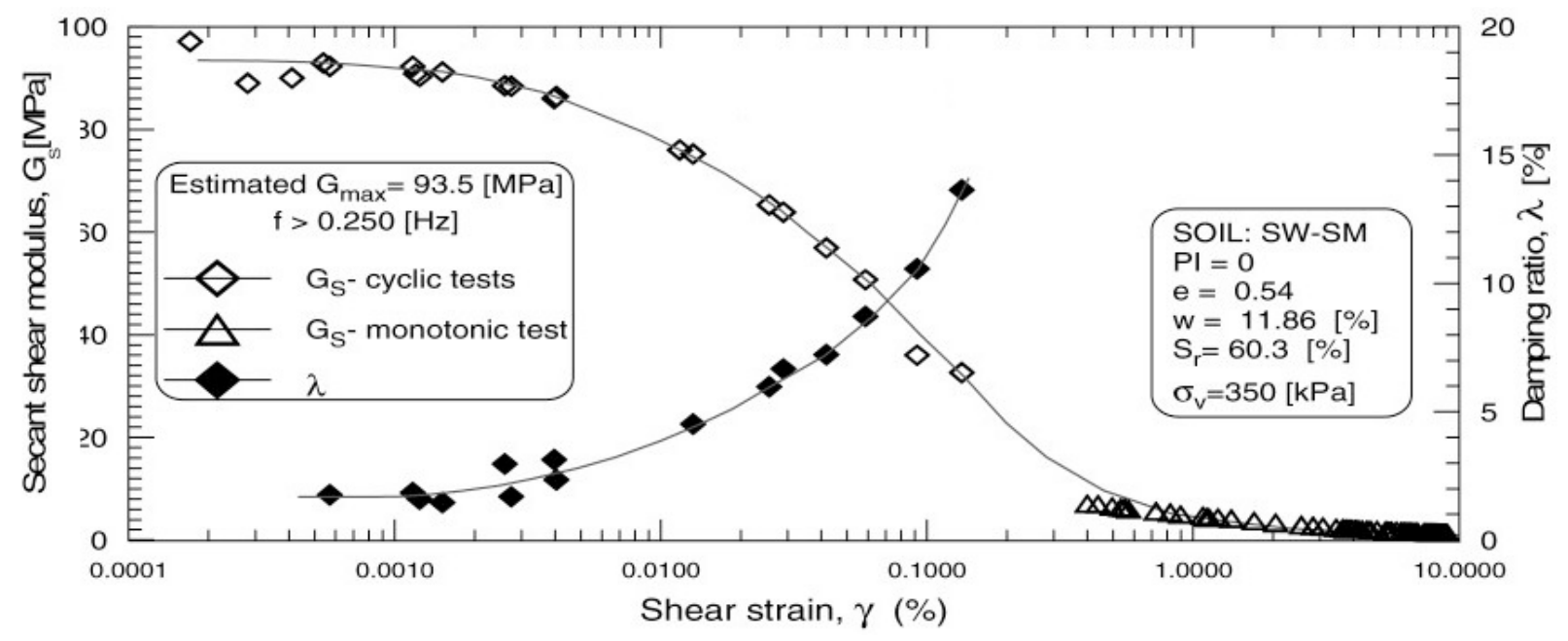

Figure 14. Changes in shear modulus and in damping ratio for a SW-SM soil under cyclic loading (after [8])

The thickness of the fill presumably is known from the construction records. The thickness of the tuff layers under BSL-3 has not been documented, although work is ongoing to that effect (private communication from T. Houston, October 18, 2006). 
The in-situ shear wave speed $V_{S}$ of the fill is not known. That could be obtained with CPT tests performed next to BSL-3 that include the use of a seismic system. Then the initial shear modulus of the fill is $G_{f}=\rho V_{s}^{2}$, where $\rho$ is the mass density of the fill.

The $V_{\mathrm{s}}$ for the tuff layers can be taken from [3], as shown in Table1. The field shear modulus of the tuff layers can be estimated from their field deformation modulus $\mathrm{E}_{\mathrm{f}}$ as $\mathrm{G}_{\mathrm{f}}=\mathrm{E}_{\mathrm{f}} / 2(1+v)$, with $v=0.25$. The $\mathrm{E}_{\mathrm{f}}$ can be obtained as the modulus of the intact rock cores multiplied by a reduction factor, as indicated below. Cores were obtained for tuff layers of area TA-3, but only the unconfined compressive strength has been reported. These cores should be retested for Young's modulus. If they are damaged or no longer available, new cores should be obtained. Then, an estimate of the reduction factor can be derived from the GSI, as shown in Figure 15.

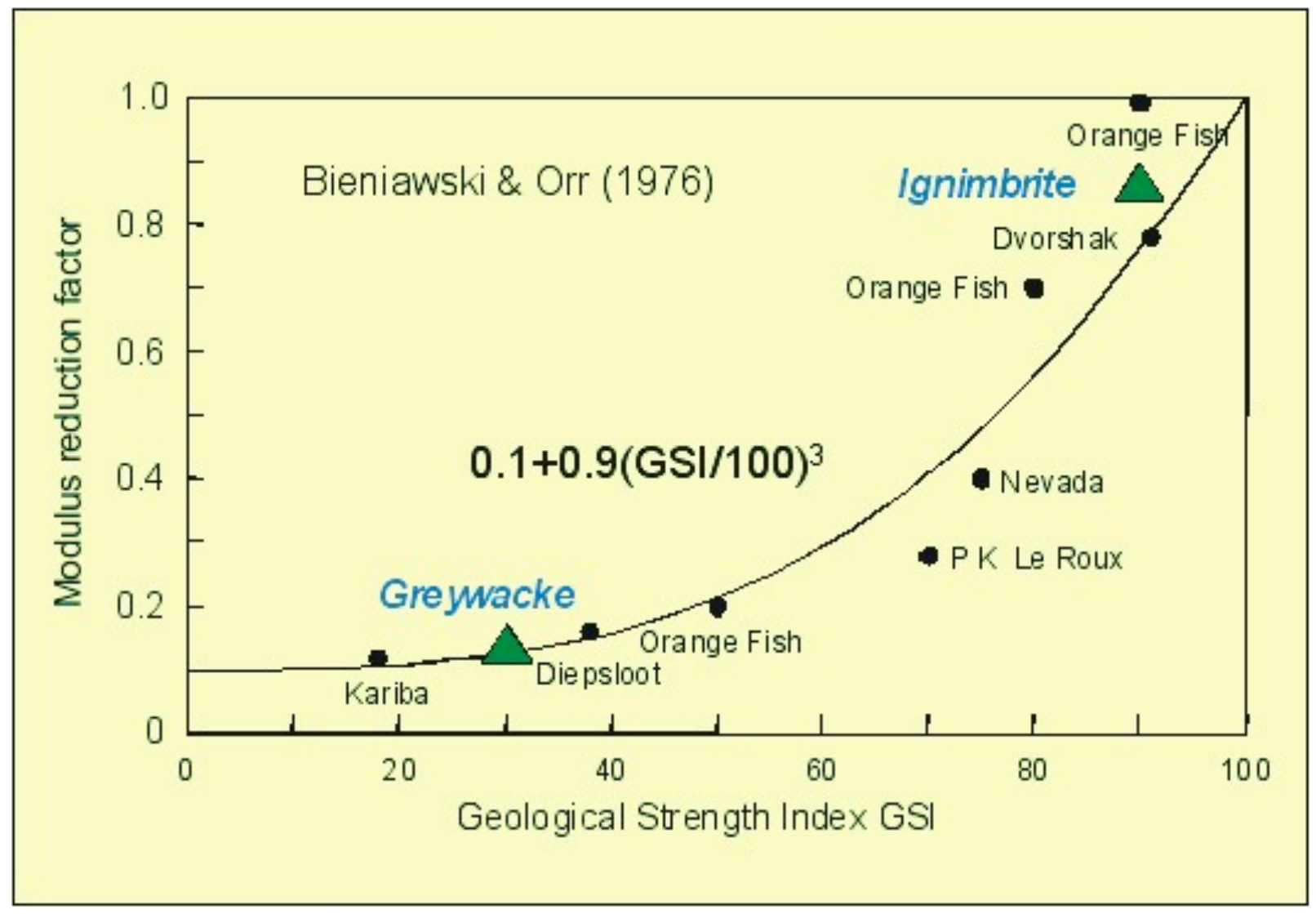

Figure 15. Rock mass modulus reduction factor as a function of GSI (after [9]).

\section{SUMMARY}

This review of the LANL BSL-3 slope stability analysis has led to the conclusion that the stability analysis was inappropriate for the following reasons:

- the assumption of a circular failure surface through the combined fill-and-rock foundation does not recognize the geologic structure involved. 
- the assumption of an equivalent static force to an earthquake loading does not represent the multiple cycles of shear loads created by a seismic event that can engender a substantial degradation of shear modulus and shear strength of the soil under the building [2].

- there was no credible in-situ strength of the foundation materials (fill and rock mass) available for input into the stability analysis.

Then, a new procedure was suggested in case that NNSA personnel want to request that additional, more relevant analyses be performed.

\section{REFERENCES}

1. Costantino, C., and Houston, T., "Evaluation of Slope Stability at the Biosafety Level 3 Laboratory", Los Alamos National Laboratory Report L-14168, 28p., February 2005.

2. Heuze, F., Archuleta, R., Bonilla, F., Day, S., Doroudian, M., Elgamal, A., Hoehler, M., Lai, T., Lavallee, D., Lawrence, B., Liu, P-C., Martin, A., Matesic, L., Mellors, R., Minster, B., Oglesby, D., Park, S., Riemer, M., Steidl, J., Vernon, F., Vucetic, M., Wagoner, J., and Yang, Z. "Estimating Site-Specific Strong Earthquake Motions", Soil Dynamics and Earthquake Engineering, v. 24, n. 3, pp. 199-223, 2004.

3. Wong, I. et al, "Seismic Hazards Evaluation of the Los Alamos National Laboratory", Final Report, vols. 1-3, by Woodward-Clyde Federal Services, Oakland, CA, February 1995.

4. Reneau, S. L., Broxton, D. E., Carney, J. S., and LaDelfe, C., "Structure of the Tshirege Member of the Bandelier Tuff at Mesita del Buey, Technical Area 54, Los Alamos National Laboratory”, Los Alamos National Laboratory Report LA-13538-MS, 16 p, 1998.

5. Kleinfelder Inc. "Geotechnical Engineering Report, CMMR Project", Report DCN 19435.10528.5-ALB06RP002, Kleinfelder, Albuquerque, NM, 282p., June 30, 2006.

6. Oruch, T. "LANL Engineering Standards Manual OST220-03-01-EM", Report LA-UR02-6639, updated June 6, 2006.

7. Hull, R. W., "New BSL-3 EA Data Needs. As-Built BSL-3 Facility Seismic, Geologic, Structural Engineering Questions", February 13, 2004, 9p., provided by Tetra Tech Inc., Round Rock, TX, to Dr. R. Thorpe, Aug. 11, 2006.

8. Archuleta, R., Elgamal, A., Heuze, F., Lai, T., Lavallee, D., Lawrence, B., Liu, P-C., Matesic, L., Park, S., Riemer, M., Steidl, J., Vucetic, M., Wagoner, J., and Yang, Z. "Strong Earthquake Motion Estimates for Three Sites on the U.C. Riverside Campus", Lawrence Livermore report, UCRL-ID-140522, 68 p., 2000. (http://www.llnl.gov/tid/lof/documents/pdf/238854.pdf).

9. Richards, L., and Read, S. "Use of Rock Mass Classification for Estimating Rock Mass Deformability", unpublished discussion notes, 10th ISRM Congress, Johannesburg, S. Africa, 2003 (Powerpoint presentation available from F. Heuze, courtesy of Richards and Read). 
University of California

Lawrence Livermore National Laboratory

Technical Information Department

Livermore, CA 94551

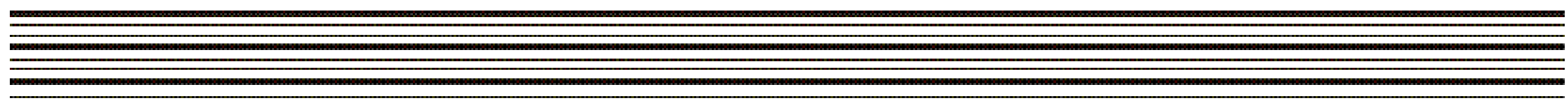

